\title{
Sustainability of Relationship between Business and Political Actors in Local Government Election
}

\author{
Fitriyah \\ Department of Politics and Government \\ Faculty of Social and Political Sciences, Diponegoro University \\ Semarang, Indonesia \\ fitriyasemarang@yahoo.co.id
}

\begin{abstract}
One component of a candidate's spending that caused high cost in direct election was the practice of money politics. In this context, the candidate's access to financial resources becomes essential. Political funding was needed in large numbers, creating spaces for the businessmen to become political investors for economic gain. The purpose of this study was to analyze the involvement of businessmen as investors at regency level. The research site was in Demak Regency of Central Java. The defeat of incumbents in Demak not be separated from political movements made by businessmen as the investors. The study used qualitative descriptive approach. Data were collected with in-depth interviews to 6 intentionally selected informants (purposive sampling), supported by secondary data from relevant documents. Data were analyzed using qualitative analysis. The result showed that there was a corruptive relationship between businessmen and the rulers, in which the businessmen became political investors and after election they could rearrange local government's project budget. The study also found that there was a sustainability of relationship between business and political actors from the previous elections. This research suggested to reduce the role of political investors and political spending of the candidate for money politics by theimplementation of effective regulations.
\end{abstract}

Keywords- Local government election, sustainability, political investor, political spending

\section{INTRODUCTION}

Since June 2005, the position of Indonesian regional heads such as governor, regent, and mayor (for provinces, regencies, and municipalities, respectively) has been directly chosen by the people, while previously by the local council. Compared to the prior system, the direct election requires higher political cost borne by the government and the competing candidates because of the large amount of voters. One component causing the high expenses in direct election is money politics practice. In this context, candidates' access to money resources becomes essential, since it may threaten the democracy by influencing voters' ballot. As a result, the election is more advantageous for candidates with large amount of money or having access to such resources.

Almost all candidates in every local election did money politics. It was proved by Constitution Court's decision to cancel the election result in several regions which was based on massive money politics practices [1]. In money politics, there are interactions between political actors and economic actors inside a local election's political circulation. In most cases, economic actors are businessmen who also act as the candidate's funders [2], [3]. The flow of fund from those businessmen has a post-election implication. Those businessmen will have special rights such as political and economy protection [4]. Studies conducted by Hidayat [2], [5], [6], [7] found the presence of funders/political investors causing post-election clientism among economic elites and political elites in some provinces. From that study it was known that local election was interfered with political and business conspiracy, and after elected, the regional head would be more loyal to his political and business clients compared to his constituents. It was also found that local election created powerful people with solid local base called local strongmen. That construction was also found in local bossism phenomenon in the Philippines, chao pho in Thailand [8], and also godfathers in Nigeria [9]. It is interesting that those mentioned countries were socially and economically similar. Either incumbent regent or vice regent's loss was suspected to have relationship with political movements conducted by funders with preference to the winning candidate. Through capital power, the businessmen could provide economic fund such as credits or donations to the candidate. This economic need was related with the widely increased money politics practices to gain voters' support. In the end, the donation was not free, but there is a post-election feedback

\section{RESEARCH METHODS}

This article was based from field research using quantitative research method with case study approach. Primary data were collected from in-depth interview with 6 informants, which were party manager, businessman, candidate surveyor, politics observer/academician, reporter, and voter. Secondary data were obtained from online news, newspapers, and official documents from KPU Demak (Election Bureau).

\section{RESULT FINDINGS AND DISCUSSION}

Since 2015, local elections have been designed to be nationally simultaneous and conducted in batches according to regional heads' end of terms, and in 2027, it will be conducted simultaneously for all regions in Indonesia. The first simultaneous local election on $9^{\text {th }}$ December 2015 was arranged in 264 provinces and regencies/municipalities. From 
35 regencies in Central Java Province, there were 21 regencies running elections including Demak.

Demak is a muslim majority area with $99,16 \%$ of its population are muslims and most are affiliated to Nahdlatul Ulama (NU), Indonesian biggest Muslim organization. Historically, Demak regency was the location of the first Islamic kingdom in Java which was established by Raden Fattah in 1478. Religious tourism grows well in Demak with Grand Mosque of Demak (built in 1401) as one of the oldest mosque in Indonesia and is considered as the heritage of Wali Songo and Raden Fattah himself. It is also a rice producing region and there are many middle class working as rice merchants. However, the percentage of poor citizens is high with $15.72 \%$ of all residents, slightly higher than Central Java poverty rate (14.4\%) in 2003.

Islam also influences political views of Demak citizens. PPP, an Islamic party, had significant voters in orde baru (new order) era. In post order times, Islamic or Muslim based parties are still considered strong. Election candidates were often figures from NU. The first post reformation election in 2001 was executed by the local council which resulted in Endang Setyaningdyah-KH Nurul Huda's victory. The first direct election in 2006 resulted in Tafta Zani - KH M. Asyiq's triumph and the 2011 election resulted in Tafta Zani-Dachirin Said's win. Although Dachirin Said was not entitled as a Kyai, he was an NU figure (Mustasyar NU Demak). Consistently, Natsir, the elected regent in 2015, is also an NU figure.

The 2015 election was the third direct election in Demak. The first one was organized on $26^{\text {th }}$ February 2006 and the second was arranged on $6^{\text {th }}$ March 2011. Four candidate pairs participated in both elections. The winner of 2006 election was Tafta Zani-KH M. Asyiq and he was successfully reelected in 2011 with his vice, H.M.Dachirin Said. After Tafta Zani's death in the first year of his second term, Dachirin succeeding him as Demak's regent on December 2013 with Harwanto as his vice, appointed by the local council.

In 2015 election, there were three candidate pairs in the full name: the incumbent regent H.M. Dachirin Saidbusinessman Edi Sayudi; incumbent vice regent Harwantopolitician H. Maskuri; and civil servant H.M.Natsir- pensioner Joko Sutanto. All pairs were proposed by coalition of parties who had seats in the local council. The party or the coalition was required to have at least $20 \%$ of all seats or 10 seats in order to nominate a candidate.

The Natsir-Joko pair was proposed by PPP and Partai Golkar coalition (14 seats), Dachirin-Edi by PKB dan Partai NasDem coalition (12 seats), and Harwanto-Maskuri by Partai Gerindra, PAN dan Partai Demokrat coalition (12 seats). PDIP with 9 seats and PKS with 4 seats did not propose any candidate, but after candidacy confirmation, PDIP announced its support to Natsir-Joko pair while PKS supported DachirinEdi. The Natsir-Joko pair won the election with $54.21 \%$ vote. Their victory was spread equally among all 14 districts, meaning that the both incumbents were lost in their hometown district.

Natsir was known to have social assets since his position as the head of PGRI (Teacher's Union) Demak, head of
Pramuka (Scouts), and a civil cervant with latest position as the head of educational bureau of Demak. His pair, Joko, was a civil servant pensioner with latest employment as the head of development of Demak. His rival was an incumbent with wellknown social assets either. Dachirin used to be a vice regent, and after Tafta Zani (his precedesor) died in 2012, he was appointed to be the regent in 2013 with Harwanto as his vice until 2016. Prior to a regent, he was a civil servant in Department of Religion. Besides a regent, he was a Kyai, the Head of Pilgrimage Brotherhood Association (IPHI), Vice Head of NU Demak, and a member of Grand Mosque of Demak's council. Harwanto was a civil servant with bright career. His latest position was the $1^{\text {st }}$ Assistant and he used to be Head of several districts and worked in financial departments in Demak Regional Secretary Office. Dachirin's partner, Edi was a retail businessman who own karaoke business. Harwanto's partner, Maskuri was the Vice Head of Demak Regional Council (DPRD) and the Head of Local Representative Council (DPC) of Partai Gerindra. He used to be a politician of PKB.

Money politics in local election was not something new. The victory of Tafta Zani-Dachirin was also contributed by money politics. Study conducted by Masadji (2014) found that the victory of incumbent Tafta Zani-Dachirin pair was supported by: an opinion that he successfully developed Demak by establishing concrete roads between village on his first term, and also money politics by distributing breakfastsubstitution or working-substitution money for the voters.

Money politics was common in Demak 2015 election as confessed by B, a voter, who together with his wife accepted Rp 15.000 rupiah from their neighbour who acted as a gapit (a village level campaign team whose work is to find voters who will choose a candidate and distribute the money to the voters).

Aspinall and Sukmajati [10] used the patronage and clientelism to explain money politics practice in elections. Patronage refers to goods or other benefits distributed by politicians to the voters. Clientelism refers to the relation characteristics between politicians and the voters. They found that patronage was often performed with cultural virtues (religious or social) such as charity and generousness, therefore it will be returned with thankful feedback from the voters. The same thing happened in Demak where its people's religious view of life did not annihilate the presence of money politics. The people were accustomed with money politics and considered it as something common, even viewing it as an "obligatory" gift from the rich to the poor. Other studies also found that money politics are easier found in poor areas, not only because of the candidate's will to gain votes but also voters' needs [11]. In poor areas, money politics is effective when the voters realized that they were watched [12]. This pattern was found in Demak which was a region with mean poverty percentage higher than average rate of Central Java Province. Culturally, the voters had bond with money givers, together with cultural values such as "internal observation", which created a reciprocal relationship. 
He was then discovered to do money politics after his candidacy in 2015 simultaneous local election. Less than a month before voting day, Dachirin had survey data which showed that he was lost from Natsir-Joko pair, yet he still distributed money to the voters. His pair, Edi, did not want to break his promise and kept his good name as a businessman for his nomination in future election.

A high political cost opens opportunities for political funders, mostly businessmen, to donate for a candidate. The donation takes form as a loan which should be returned in previously agreed form, period, and amount. Studies conducted by Hidayat [2], [5], [6], [7] found that donations from the businessmen created a shadow state and informal economy. These patterns were found in Demak.

The presence of the local strongmen is connected to their ability to fund and to win the candidacy competition in local elections. For instance, in Nigeria, a candidate needs a godfather who he depends on. With this relationship, a candidate's popularity does not significantly affect the election result because the chosen godfather will ensure his electoral triumph. The godfather's role becomes clearer and more effective after election [13]. The presence of local strongman was also found in Demak.

There was a businessman known as a "king maker" in 2015 Demak election. He was a well-known figure in Demak as construction projects businessman and the head of local business organization. His work as a contractor were often related with government's projects. His figure attracted mass media's attention since he led a protest opposing the "fee" policy for local projects during Endang Setyaningdyah's leadership (2001-2006). He, together with construction businessmen allied in various construction workers' organizations did a protest on Tuesday, $26^{\text {th }}$ July 2005 which ended tumultuously. Many were injured due to clash with police officers.

Big Boss' opposition towards Endang's nomination in 2006 election was shown by his and other construction service businessmen help to her rival, Tafta Zani. The election was participated by 4 candidate pairs including incumbent regent, Endang Setyaningdyah and vice regent, KH. Nur Hamid Wijaya. Both were lost to Tafta Zani (ex-Demak Secretary of Region). In 2015 election, Big Boss supported Natsir-Joko pair, with Joko as a bureaucrat had a working relationship with him. Big Boss was originally proposed as a regent candidate from business background yet he chose not to, and became a sponsor for another candidate. The candidate was Natsir since his wide networks as the Head of PGRI and Pramuka potentially gave him advantagesforthe election.

Big Boss worked behind the screen. As a construction businessman he needs to get projects from local government, so that he had to plant "people" in the government. His choice fell to Natsir and Joko. Like every business person's involvement in local elections, Big Boss was the sponsor for the pair. The election contest required large fund, either for official and legal activities or unlawful ones such as money politics to buy votes or bearing parties (dower money). Big
Boss also did lobbying to Natsir-Joko bearing parties, including PDIP, although the party later only support the pair.

The funders' role was limited until money distribution to the voters. The distribution was performed by candidates' campaign team, often unofficial volunteers who were not registered in the KPU (Election Bureau). It is not uncommon for candidates with wide networking to use their organizations for political machines besides the parties.

\section{CONCLUSION}

This study's finding had similarities with studies conducted by Hidayat in some provinces such as Gorontalo, Jambi, South Kalimantan, Bengkulu, and West Sumatra and Riau Islands which found the post-election relationship between businessmen as political investors and politicians created local strongmen as shadow states. However, Big Boss' post-election role was limited to controlling local infrastructure projects not all local government's public agendas. In this case, Big Boss was a pure businessman. His profession required dependency with local government's projects and pushed him to gain good connections with the regent. He finally found his way as a funder. As a result, together with his allies, he received feedbacks in the form of business sustainability's guarantee from building local infrastructure projects. He did not work alone because he had field operators from his fellow businessmen which some were party members. It was not out of possibility if someday regeneration grows in the succeeding elections. The involvement of businessmen as election funders happened because of large expenses a candidate ought to borne to be nominated and selected through money politics. Their relationship was corruptive in nature. From those facts, election regulation interventions and voters educations were urgently needed such as the need of a regulation to ensure candidate's incoming fund and expenses' transparency and accountability. The need of a regulation to ensure law enforcement to money politics for candidacy buying and vote buying. The need of massive voters' education to enhance voters' awareness about the value of a vote and choosing risk for the next 5 years' leadership.

\section{ACKNOWLEDGMENT}

The author declared no potential conflict of interest on this article.

\section{REFERENCES}

[1] Junaidi, Veri. 2010. "Systematic, Structured, and Massive Violation: A Cause of People's Will Cancellation in 2010 Election" ("Pelanggaran Sistematis, Terstruktur, dan Masif: Suatu Sebab Pembatalan Kehendak Rakyat Dalam Pilkada Tahun 2010”), Jurnal Konstitusi, vol 7 . no 5, pp. 41-72

[2] Hidayat, Syarif (ed), 2006. "Business and Politics on Local Level: Businessmen, Rulers, and Post Election Local Governance (Bisnis dan politik di tingkat lokal: Pengusaha, Penguasa dan Penyelenggaraan Pemerintahan Daerah Pasca Pilkada )". Jakarta: LIPI Press.

[3] Mietzner,Marcus. 2011. "Funding Pilkada : Illegal campaign financing in Indonesia's local elections", in Edward Aspinall and Gerry van Klinken, (eds), The State And Illegality In Indonesia, Leiden: KITLV Press, , pp. 123-138 
[4] Agustino, Leo and Yusoff, Muhammad Agus, 2010. "Local Elections and Regional Expansion in Indonesian Local Democracy: Local Strongmen and Roving Bandits ("Pilkada dan Pemekaran Daerah dalam Demokrasi Lokal di Indonesia: Local Strongmen dan Roving Bandits"), Malaysian Journal of History, Politics, \& Strategic Studies, vol. 37, pp. 86-104

[5] Hidayat, Syarif. 2007. "Shadow State: Business and Politics in Banten Provine ("Shadow State: Bisnis dan Politik di Provinsi Banten)", in HS Nordholt dan G. van Klinken (eds), Politik Lokal di Indonesia,Leiden: YOI \& KITLV, pp. 267-303

[6] Hidayat Syarif. 2010. "Elite Democracy? The Relationship of Post Election Power ("Demokrasi Elitis? Relasi Kekuasaan Pasca Pilkada"), Jurnal Masyarakat Kebudayaan dan Politik, vol. 23. no. 3, , pp. 169-180

[7] Hidayat, Syarif and Susanto, Hari (eds), 2006. Business and Politics on Local Level (Bisnis \& Politik di Tingkat Lokal), Jakarta: LIPI Press.

[8] John Sidel, 2004. "Bossism and democracy in the Philippines, Thailand, and Indonesia: towards an alternative framework for the study of 'local strongmen'," in John Harriss, KristinStokke, and Olle, Tornquist, (eds.) Politicising Democracy: the New Local Politics of Democratisation. International political economy series, Basingstoke, UK: Palgrave Macmillan, pp. 51-74
[9] Otite, Atare and Umukoro, Nathaniel. 2010. "Money Politics, Political Culture of Godfatherism and the Future of Democracy in Nigeria: Lessons from the 2007 Gubernatorial Election in Edo State," Africana vol. 4. no. 2. pp. 65-79

[10] Aspinall, Erdward and Sukmajati, Mada (eds), 2015. Money Politics in Indonesia: Patronage and Clientelism in 2014 Legislative Election (Politik Uang Di Indonesia: Patronase dan Klientelisme Pada Pemilu Legislatif 2014), Yogyakarta: PolGov,

[11] Cendales, Andres. 2012. "Vote Buying, Political Patronage And Selective Plunder", Latin American Journal of Economics, vol. 49, no. 2, pp. 237-276

[12] Valeria, Brusco; Nazareno, Marcelo; Stokes, C Susan.. 2004. "Vote Buying In Argentina,” Latin American Research Review, Vol. 39, No. 2, pp.66-88.

[13] Korikye, M. C. Wenibowei, 2011. "Political Godfatherism, Violence And Sustainable Democracy in Nigeria," International Journal of Advanced Legal Studies and Governance, vol.2, no.1, April, pp. 113125 